\title{
Health Workers Perception on Constraints to Effective Administration of Quality Care to the Mentally Ill Patients.
}

\author{
*Agbapuonwu, Noreen E. ${ }^{1}$, Iheanacho Peace ${ }^{2}$, Ilo, Clementine I. ${ }^{1}$, Makata, \\ Ngozi E. ${ }^{3}$, Chinweuba, Anthonia U. ${ }^{2}, \&$ Obasi, Stella C. \\ ${ }^{l}$ Department of Nursing Science Nnamdi Azikiwe University Nnewi Campus Anambra State. Nigeria \\ ${ }^{2}$ Department of Nursing Sciences University of Nigeria Enugu Campus Enugu State, Nigeria \\ ${ }^{3}$ Nursing Services Department Ministry of Health Headquarters Enugu Enugu State, Nigeria \\ ${ }^{4}$ Department of Human Kinetic and Health Education Anambra State University Uli. Anambra State, Nigeria
}

\begin{abstract}
Mental health services which should have been fully mainstreamed into Primary health care with an approach to improve primary prevention and address the risk factors of mental illness have often been identified as one of the most neglected areas of the health services. This study examined the Perception of health workers on the constraints to effective administration of quality health care to the mentally ill patients in psychiatric hospital in Anambra State, Nigeria. Two research questions and two hypotheses guided the study. Related literatures were reviewed. By purpose based classification scheme, descriptive survey research design was used. The study population consisted of all the thirty (30) health workers met on duty during the period of data collection. The instrument used for data collection was self-developed, structured, validated and reliable questionnaire which was administered on a face-to-face basis to the respondents. Data collected were analyzed using chi-square $\left(x^{2}\right)$ to test the hypotheses for results at 0.05 level of significance. The result revealed that the constraints as perceived by the health workers were found to be the same irrespective of their area of specialization and years of service at the institution. Based on the findings, it was concluded that there were significant relationship between the health worker's area of specialization and their perception of the constraints to administration of quality health care to the mentally ill patients. The length of service of the health workers also had significant relationship with their perception of constraints to administration of quality health care to the mentally ill patients. It was recommended that government should pay more attention to mental health by integration into Primary health care, recruit more mental health personnel and provide proper treatment facilities.
\end{abstract}

\section{Background to the Study}

\section{Introduction}

Health according to World Health Organization (WHO) is the state of complete physical, mental and social wellbeing and not merely the absence of disease or infirmity. However, there is no indication that any of the states should have precedence over the other. The World Health Organization further described mental health as "a state of well-being in which the individual realizes his or her own abilities, can cope with the normal stresses of life, can work productively and fruitfully, and is able to make a contribution to his or her community" (WHO, 2005). Mental Health is not just the absence of mental illness.

Mental illness is described as 'the spectrum of cognitive, emotional, and behavioural conditions that interfere with social and emotional wellbeing and the lives and productivity of people. Having a mental illness can seriously impair temporarily or permanently, the mental functioning of a person (http://en.wikipedia.org/wiki/Health).

Mental illness occurs when there is maladjustment in a person's life, producing disharmony in thought, feelings and actions. The individual losses the ability to respond according to expectations he has for himself and the demand of the society reflecting the extent of his emotional, psychological and physical dysfunction.

Mental health problems are among the most important contributions to the global burden of disease and disability. According to estimates by WHO (2006), mental and neurological conditions account for about 12.3 per cent of disability-adjusted life years (DALYs) lost globally, and for 31 per cent of all years lived with disability at all ages and there is no culture free from this social malady.

The degree of disturbance experienced by the mentally ill patient may vary from mild neurotic reaction to severe psychotic cases. When the incapacitation is much less so as to allow the patient to go about his business and could be treated on an outpatient basis, he reports to the hospital for drug prescription and periodic evaluation. When the incapacitation is sufficiently great, it becomes necessary to hospitalize the patient where he will not be harmful to himself and to others. The aim of hospitalization is to provide the individual with an opportunity to preserve and enhance his personal and social functioning and to provide his coping abilities. 
Mental health services have often been identified as one of the most neglected areas of health services. Awases, Gbary, Nyoni and Chatora (2003);Manafa, McAuliffe, Maseko, Bowie, MacLachian, and Normand (2009) acknowledged that the health workforce is insufficient and will be a major constraint in attaining the Millennium Development Goals (MDGs) for reducing poverty and disease. This may have created a lack of capacity to deliver quality mental health services which is based on scientific knowledge of psychiatric professionals (Gezaairy, 2004; Odejide \& Marakinyo, 2003).

According to Loschen (2007) the situation in many African countries is that only about 43 per cent of treatment for mental disorder is available in Primary Health Care. Mental health services should be fully mainstreamed into Primary Health Care with an approach to improve primary prevention and address the risk factors. Oguntola (2007) opined that about 76 per cent of the countries in Africa have less than one psychiatric bed per 10,000 people and 96 per cent of the countries have less than one psychiatrist per 10,000 population. Oguntola further explained that only 52 per cent have a substance policy, 41 per cent do not have a specific mental health budget and another 31 per cent allocated less than 1 per cent of the total budget to mental health care services. These statistical data according to Oguntola (2007) show the high burden and lack of resources in the African region of which Nigeria is no exception.

Reports have shown that despite the need for mental health services evidenced by the high prevalence of mental disorders, only a minority of mentally ill persons receive treatment in the health care system (Kessler, Zhao \& Katz, 2009). However, there is paucity of research on the health workers' perceptions of the constraints to effective administration of quality health care to the mentally ill patients in Nigeria. It is very unlikely that health workers set out to treat patients badly, thus there must be reasons why mentally ill patients do not receive the needed treatment. In a study done by Fonn and Xaba (2000), it was observed that health workers identified many constraints which have affected their provision of adequate health services and their relationship with their clients. These constraints as confirmed by Loschen (2007) include shortage of trained personnel, adequate treatment equipment and inadequacies in the government polices giving low priority to the management of mental health services. In view of the above problems it becomes necessary to ascertain the perception of health workers on the constraints to effective administration of quality health care to mentally ill patients in Anambra state.

\section{Purpose of the study}

The main purpose of the study is to determine the health workers perception on the constraints to effective administration of quality health care to mentally ill patients in Anambra State, Nigeria. Specifically, the study aimed at:

1. Determining the constraints to effective administration of quality health care to mentally ill patients as perceived by the subjects of the study based on their years of experience.

2. Determining the constraints to effective administration of quality health care to mentally ill patients as perceived by the subjects of the study based on their area of specialization

\section{Research Questions}

1. What are the subjects' perception of the constraints to effective administration of quality health care to mentally ill patients based on their years of experience?

2. How does area of specialization of the subjects influence their perception of the constraints to effective administration of quality health care to mentally ill patients?

\section{Research Hypotheses}

a. The perception of the subjects about constraints to effective administration of quality health care to mentally ill patients is not significantly influenced by years of experience.

b. The perception of the subjects about constraints to effective administration of quality health care to mentally ill patients is not significantly influenced by their areas of specialization

\section{Methodology}

This was a descriptive survey research at the psychiatric hospital in Anambra State, Nigeria. The researchers used convenience sampling that included all the different cadres of health workers available and willing to participate in the research. The objectives of the study explained to participants and confidentiality was assured and informed consent received from them before they were included in the study. A pre-tested selfdeveloped questionnaire were was utilized to elicit responses from the respondents.

\section{Method of Data Analysis}

The data collected were organized and analyzed using frequencies and percentages for the research questions and chi square for testing the hypotheses at 0.05 level of significant. 
III. Results

Table 1 showing the demographic data of the respondents

\begin{tabular}{|c|c|c|}
\hline Variable & Frequency & Percentage \\
\hline \multicolumn{3}{|l|}{ Gender } \\
\hline Male & 8 & 26.7 \\
\hline Female & 22 & 73.3 \\
\hline \multicolumn{3}{|l|}{ Age (Years) } \\
\hline $20-30$ & 8 & 26.7 \\
\hline $31-40$ & 11 & 36.7 \\
\hline $41-50$ & 8 & 26.7 \\
\hline 50 and Above & 3 & 10 \\
\hline \multicolumn{3}{|l|}{ Years of experience } \\
\hline$<5$ years & 16 & 53.3 \\
\hline $6-10$ years & 6 & 20 \\
\hline $11-15$ years & 4 & 13.3 \\
\hline$>16$ years & 4 & 13.3 \\
\hline \multicolumn{3}{|l|}{ Profession } \\
\hline Psychiatrist & 2 & 6.7 \\
\hline Nurse & 6 & 20 \\
\hline Clinical psychologist & 2 & 6.7 \\
\hline Social worker & 4 & 13.3 \\
\hline Occupational therapist & 1 & 3.3 \\
\hline Pharmacist & 3 & 10 \\
\hline Laboratory Scientist & 1 & 3.3 \\
\hline Health Assistance & 8 & 26.7 \\
\hline Dietician & 2 & 6.7 \\
\hline Medical record officer & 2 & 6.7 \\
\hline
\end{tabular}

The respondents were both male $8(26.7 \%)$ and female $22(73.3 \%)$. Their age range were $20-30$ years 8 (26.7\%), $31-40$ years $11(36.7 \%), 41-50$ years $8(26.7 \%)$ and 50 years and above $3(10 \%)$. Their years of experience in the hospital were < 5 years $16(53.5 \%)$, 6- 10 years $6(20 \%), 11-15$ years $4(13.3 \%)$ and above 15 years $4(13.3 \%)$. The respondents comprised of health assistants $8(26.7 \%)$, nurses $6(20 \%)$, social workers 4 $(13.3 \%)$, pharmacists $3(10 \%)$, psychiatrists, clinical psychologists, dieticians and medical record officers were $2(6.7 \%)$ each while occupational therapists and laboratory scientists were $1(3.3 \%)$ each.

\section{Research Hypothesis One}

The perception of the subjects about constraints to effective administration of quality health care to mentally ill patients is not significantly influenced by the years of experience.

Table 2.Table showing the years of experience in respect to perception of the constraints to effective administration of quality care.

\begin{tabular}{|c|c|c|c|c|c|c|}
\hline Constraints & $\begin{array}{l}\text { Less than } 5 \\
\text { years }\end{array}$ & $\begin{array}{l}6 \quad-10 \\
\text { years }\end{array}$ & $\begin{array}{l}\text { 11-15 } \\
\text { years }\end{array}$ & $\begin{array}{l}15 \text { years } \\
\text { and above }\end{array}$ & Chi-square & $\mathbf{R}$ \\
\hline Government policy & 2 & 7 & 8 & 13 & $50.56(\mathrm{P}<0.001)$ & $0.92(\mathrm{P}<0.001)$ \\
\hline $\begin{array}{l}\text { Shortage of trained } \\
\text { Personnel }\end{array}$ & 6 & 6 & 3 & 15 & $43.33(\mathrm{P}<0.001)$ & $0.92(\mathrm{P}<0.001)$ \\
\hline Limited resources & 15 & 10 & 5 & 0 & $48.50(\mathrm{P}<0.001)$ & $0.93(\mathrm{P}<0.001)$ \\
\hline $\begin{array}{l}\text { Low priority to mental } \\
\text { health }\end{array}$ & 1 & 6 & 10 & 13 & $40.00(\mathrm{P}<0.001)$ & $0.88(\mathrm{P}<0.001)$ \\
\hline $\begin{array}{ll}\text { Inaccessibility } & \text { of } \\
\text { psychiatric services } & \end{array}$ & 8 & 8 & 7 & 7 & $49.20(\mathrm{P}<0.001)$ & $0.94(\mathrm{P}<0.001)$ \\
\hline $\begin{array}{l}\text { Lack of equipment and } \\
\text { supplies to health workers }\end{array}$ & 3 & 5 & 6 & 16 & $57.50(\mathrm{P}<0.001)$ & $0.95(\mathrm{P}<0.001)$ \\
\hline $\begin{array}{l}\text { Poor attitude of } \\
\text { community members }\end{array}$ & 9 & 9 & 9 & 3 & $44.86(\mathrm{P}<0.001)$ & $0.87(\mathrm{P}<0.001)$ \\
\hline
\end{tabular}

When the years of working experience in the hospital was cross tabulated against the constraints and each item was tested at 0.05 level of significant, they were found to be significantly related. Most of the health workers strongly agreed with the factors listed as constraints to the administration of quality health services to the mentally ill. Therefore the null hypothesis was rejected.

\section{Research Hypothesis Two}

The perception of the subjects about constraints to effective administration of quality health care to mentally ill patients is not significantly influenced by their areas of specialization. Data on table 3 provided the answer to this research hypothesis. 
Table 3.A cross tabulation table showing the response on areas of specialization and health workers perception of how these factors affect quality of care.

\begin{tabular}{|c|c|c|c|c|c|}
\hline & \multicolumn{5}{|c|}{ How has these factors affected the services rendered } \\
\hline & Adversely & Moderately & Negatively & \multicolumn{2}{|l|}{ Total } \\
\hline Nurse & 6 & 0 & 0 & 6 & \\
\hline $\begin{array}{l}\text { Clinical } \\
\text { psychologist }\end{array}$ & 2 & 0 & 0 & 2 & \\
\hline Social worker & 4 & 0 & 0 & 4 & \\
\hline $\begin{array}{l}\text { Occupational } \\
\text { therapist }\end{array}$ & 1 & 0 & 0 & 1 & \\
\hline Pharmacist & 3 & 0 & 0 & 3 & \\
\hline Laboratory scientist & 0 & 1 & 0 & 1 & \\
\hline Health assistant & 0 & 6 & 2 & 8 & \\
\hline $\begin{array}{l}\text { Medical records } \\
\text { officer }\end{array}$ & 0 & 0 & 2 & 2 & \\
\hline Dietician & 0 & 0 & 1 & 1 & \\
\hline \multirow[t]{2}{*}{ Total } & 18 & 7 & 5 & 30 & \\
\hline & \multicolumn{2}{|c|}{ Value } & Df & & P-Value \\
\hline Chi-square & \multicolumn{2}{|c|}{44.571 (a) } & 18 & & 0 \\
\hline $\mathbf{R}$ & \multicolumn{2}{|c|}{0.843} & & & 0.35 \\
\hline
\end{tabular}

When the data were subjected to Chi-square statistics at 0.05 level of significance and 18 degree of freedom showed that the calculated $X^{2}$ of 44.57 was greater than the critical value of 0.843 . This means that there was significant relationship between area of specialization and the health worker's perception of how these factors have affected effective administration of quality health care to the mentally ill patients in Neuropsychiatric hospital Nawfia. The null hypothesis was therefore rejected.

\section{Discussion}

There have been reports of many constraints by health workers which affected their provision of adequate health services. Shortage of trained personnel, adequate treatment equipment and inadequacies in the government policies giving low priority to the management of mental health services were among the major factors. The findings from this study indicated that the areas of specialization as well as the years of experience of the health workers have significant effect on their perception of the constraints to the administration of quality health care to the mentally ill patients.

This has resulted in their working in favourable conditions and carrying out tasks sometimes beyond their capabilities which in turn raises questions about the quality of services provided. The health workers expressed concern about how these factors have affected the quality of health services. And the government policy of not posting trained psychiatric personnel working in most General hospitals in the state to work in the Neuropsychiatric hospital have affected their services adversely 18 (60\%), moderately 7 (23.3\%) and negatively $5(16.7 \%)$.

A particular worrying finding emerging from this study was that health workers retire without replacement. Only $6(20 \%)$ were nurses, psychiatrists and clinical psychologists were $2(6.7 \%)$ each while health assistants with no training on psychiatry were about 8 (26.7\%). This is in line with the studies by Awases, Gbary, Nyoni and Chatora (2003); Gezairy, (2004); and Odejide \& Marakinyo, (2003) who acknowledged that the health workforce is insufficient and will be a major constraint in attaining the Millennium Development Goals (MDGs) for reducing poverty and disease. This may have created a lack of capacity to deliver quality mental health services which is based on scientific knowledge of psychiatric professionals.

The health workers indicated having sought government intervention and even assistance from individuals and Non-Governmental Organizations without solution which is frustrating. Lack of essential supplies (equipment and drugs), high workload and lack of basic amenities such as enough ward facilities have all affected the quality of services rendered. This has confirmed the study by Fonn and Xaba (2000) and Loschen (2007) who observed that health workers identified many constraints which have affected their provision of adequate health services.

This is a serious concern that has received little attention from the government. This has received little attention in the published literature and warrants further research to establish the effect of such workers flow on the care system.

\section{Conclusion}

Many factors were identified by health workers as constraints to effective administration of quality health care to mentally ill patients in Anambra State. These need to be addressed in order to improve the quality of services rendered to the mentally ill patients. The findings highlighted the importance of recruitment, training 
and adequate remuneration of mental health personnel. Government should pay more attention to mental health by integration into Primary health care and provision of proper treatment facilities.

\section{References}

[1]. Awases, M.,Gbary, A.,Nyoni, J. and Chatora, R. (2003) Migration of Health Professionals in Six Countries: A Synthesis Report. Brazzaville: WHO. AFRO DHS.

[2]. Fonn, S. and Xaba, M. (2000) Health Workers for change: Developing Initiative retrieved September 212009 from http://heapol. Oxford Journals.org/cgi/reprint/16/suppl- 1/13.pdf

[3]. Gezairy, H. M. (2004) Development of Mental Health Services. Eastern Mediterranean health journal.7 (3). Retrieved September 3 2009 from http://www.emro.who.int/publication

[4]. Kessler, R. C., Zhao, S.\& Katz, S. J.(2009).Past year use of Outpatient Services for psychiatric problems in the National Survey. American Journal of Psychiatry, retrieved September 222009 from http://www.cpementalhealth.com/content.nih.gov.article

[5]. Loschen, E. L. (2007)The challenge of providing quality Psychiatric Service in a rural setting retrieved September 3 2009 from http://www.pubmedcentra.nih.gov.article render. fig?

[6]. Manafa, O., McAuliffe, E.,Maseko, F., Bowie, C.,MacLachian, M.\& Normand, C.(2009) Retention of Health Workers in Malawi: perspectives of health workers and district management. Retrieved September 212009 from http://www.humanresources. Health.com/content/7/1/65

[7]. Odejide, O.N.\&Marakinyo, J. E.(2003) Mental Primary Health Care in Nigeria. World Psychiatry, 2 (3) retrieved September 3 2009 from http://www.pubmedcentra.nih.gov.article render. fig?

[8]. Oguntola.S. O. (2007) Health - Nigerians need mental assessment. Nigerian Tribune retrieved September 3 2009 from http://www.tribune.com05/22006112.hum.

[9]. World Health Organization (2005). Promoting Mental Health: Concepts, Emerging evidence, Practice: A report of the World Health Organization, Department of Mental Health and Substance Abuse in collaboration with the Victorian Health Promotion Foundation and the University of Melbourne. World Health Organization. Geneva.Retrieved November 21, 2013 from http://en.wikipedia.org/wiki/Health

[10]. WHO (2006) Economic aspects of the mental health system: key messages to health planners and policy makers. Geneva. Switzerland. World Health Organization.

[11]. http://en.wikipedia.org/wiki/Health 